\title{
Kinerja Kepala Desa dalam Pembangunan Infrastruktur Desa Sidorukun Kecamatan Randangan Kabupaten Pohuwato
}

\author{
Umar Sune \\ Universitas Pohuwato Fakultas Ilmu Sosial Dan Ilmu Politik \\ umaralmarisi@gmail.com
}

\begin{abstract}
The problem in this study is the Performance of the Village Head in Infrastructure Development in Sidorukun Village, Randangan District, Pohuwato Regency and What are the inhibiting factors. As for the purpose of this study is to determine the Performance of the Village Head in Sidorukun Village Infrastructure Development, Randangan Subdistrict, Pohuwato Regency and its inhibiting factors.

The design of this study the authors chose the type of descriptive qualitative research, using descriptive qualitative study methods that describe methods that are directed to solve problems by describing or describing what the results of the study are. Data collection techniques in this study use several ways, among others, observation, namely, to look directly at and find information that is related to research, interviews, that is, to obtain information directly from respondents through a two-way communication process, namely questionnaire, list of questions from researchers to respondents either directly or indirectly. Analysis of the data where the data obtained in the field will be analyzed qualitatively. Qualitative analysis is used to describe the efforts made in the form of the performance of the village head in infrastructure development in Sidorukun Village, Randangan sub-district, Pohuwato Regency.

The results obtained show that the Performance of the Village Head in Infrastructure Development in Sidorukun Village, Randangan District, Pohuwato Regency. Seen in Coordinating community empowerment activities, Coordinating efforts to implement peace and public order and Coordinating the application and enforcement of laws and regulations is still lacking or not working as well as in village infrastructure development there is active participation of the community in development, the existence of a sense of community responsibility for development and community capacity villages to develop can be improved, this does not work and the inhibiting factors where the Internal Factors are Awareness or Willingness Factors and External Factors namely Government Leadership.
\end{abstract}

Keywords: Village Development, Village Head, Infrastructure Development. 


\section{Pendahuluan}

Penerapan prinsip-prinsip good governance dalam pengelolaan pemerintahan menjadi suatu tuntutan utama, karena masyarakat mulai kritis dalam memonitor dan mengevaluasi pelayanan dari instansi pemerintah. Disisi lain, pengukuran keberhasilan maupun kegagalan instansi pemerintah dalam menjalankan tugas pokok dan fungsinya sulit dilakukan secara obyektif, karena belum diterapkannya sistem pengukuran kinerja, yang dapat menginformasikan tingkat keberhasilan secara obyektif dan terukur dari pelaksanaan program-program disuatu instansi pemerintah. Organisasi didirikan sebagai suatu wadah untuk mencapai suatu atau beberapa tujuan.

Organisasi tersebut harus mengelolah berbagai dan rangkaian kegiatan yang diarahkan menuju tercapainya tujuan organisasi. Pelaksanakan rangkaian kegiatan dalam organisasi dilakukan oleh manusia (humanbeing) yang bertindak sebagai aktor atau peserta dalam organisasi yang bersangkutan, maka dengan sendirinya kinerja (performance) organisasi yang bersangkutan banyak tergantung pada perilaku manusia yang terdapat dalam organisasi tersebut. Memasuki era globalisasi seperti sekarang ini, salah satu tantangan terbesar yang dihadapi oleh pegawai birokrasi pemerintahan daerah sebagai personifikasi pemerintahan yang kita kenal selama ini adalah menampilkan profesionalisme dan mandiri dalam pelayanan publik. Proses pembangunan nasional yang berlangsung dewasa ini sedang mengalami pergeseran dari bingkai sistem otoriter ke sistem demokrasi.

Hal ini menyebabkan penyelenggaraan pemerintahan menjadi sorotan yang tajam, terutama dalam aspek transparansi, akuntabilitas, efisiensi dan efektifitas. Dalam konteks ini, penerapan prinsip-prinsip good governance dalam pengelolaan pemerintahan menjadi suatu tuntutan utama, yang di tandai dengan semakin terbentuknya masyarakat dalam memonitor dan mengevaluasi manfaat serta nilai yang diperoleh atas pelayanan dari instansi pemerintah.

Birokrasi sedang bergeser dari paradigma sentralistik ke desentralistik, dari otoritarian keegalitarian dan demokratis, dari kedaulatan Negara ke kedaulatan rakyat, dari organisasi yang besar menjadi ramping tapi kaya fungsi, dari rowing (semua dikerjakan sendiri) menjadi stering (mengarahkan). Upayaupaya tersebut masih dibayangi oleh ketidakpastian dan sedang mencari 
bentuk yang tepat. Pada dasarnya upaya tersebut diarahkan untuk mendapatkan dukungan administrasi negara yang mapan mengenai kelancaran dan keterpaduan pelaksanaan tugas dan fungsi birokrasi dalam mewujudkan administrasi yang makin handal, professional, efisiensi, efektif serta tanggap terhadap aspirasi rakyat dan dinamika perubahan lingkungan.

Salah satu gejala yang tampak dalam proses pergeseran ini adalah makin meningkatnya perhatian aspek budaya dalam studi organisasi. Tidak hanya sebagai salah satu bagian penting dalam studi organisasi, tetapi konsep budaya dipergunakan sebagai metafora untuk menjelaskan perwujudan dan hakekat organisasi. Penggunaannya dalam analisis organisasi, budaya tidak hanya dipandang sebagai sesuatu yang ada dan hidup dalam suatu organisasi, tetapi juga sesuatu yang dipergunakan sebagai landasan pemikiran dalam pemahaman organisasi. Sebagai suatu variabel dalam organisasi, budaya dipelajari sebagai bagian dari sistem organisasi secara keseluruhan.

Dalam konteks ini, budaya dilihat sebagai sesuatu yang hidup di suatu organisasi yang mengikat semua anggota organisasi dalam upaya mencapai tujuan bersama. Budaya juga dapat dilihat sebagai bagian dari suatu lingkungan organisasi yang mempengaruhi perilaku dan penampilan (performance) organisasi. Analisis terhadap kinerja birokrasi publik menjadi sangat penting atau dengan kata lain memiliki nilai yang amat strategis.

$$
\text { Informasi mengenai kinerja }
$$
aparatur dan faktor-faktor yang ikut berpengaruh terhadap kinerja aparatur sangat penting untuk diketahui, sehingga pengukuran kinerja aparat hendaknya dapat diterjemahkan sebagai suatu kegiatan evaluasi untuk menilai atau melihat keberhasilan dan kegagalan pelaksanaan tugas dan fungsi yang dibebankan kepadanya.

Oleh karena itu kinerja merupakan analisis interpretasi keberhasilan dan kegagalan pencapaian kinerja. Penilaian kinerja aparatur merupakan suatu kegiatan yang sangat penting karena dapat digunakan sebagai ukuran keberhasilan organisasi dalam mencapai misinya. Terbatasnya informasi mengenai kinerja aparatur terjadi karena kinerja belum dianggap sebagai suatu hal yang penting sehingga tidak jarang ditemukan dalam perekruitan suatu jabatan yang didasarkan pada pertimbangan like and dislike pimpinan serta masih melekatnya budaya paternalisme. Secara mental 
setiap aparat birokrasi, masih ditemukan adanya tradisi dan tata pergaulan yang bersifat paternalisme, misalnya dihadapan pimpinan dinas, seorang aparat bawahan sulit untuk menunjukan penolakannya atas suatu ide atau gagasan pimpinan.

Penolakan atas ide pimpinan secara terbuka dapat berarti membuka konflik antara pimpinan dan bawahannya. Disamping itu, kendala yang dihadapi dalam rangka peningkatan profesionalisme aparatur adalah inovasi dan kreativitas aparat birokrasi masih relatif rendah. Hal ini dapat ditunjukan pada kondisi riil yang ada yakni manakala Pimpinan melakukan Tugas (Dinas) Luar, maka ada anggapan bahwa tugas dan tanggung jawab yang ada pada bawahan dapat ditunda pelaksanaannya atau dengan kata lain bawahan selalu menunggu pimpinan kembali untuk meminta petunjuk kepada pimpinan terhadap pelaksanaan tugas pokok dan fungsinya sehingga pelaksanaan tugas bawahan senantiasa harus dalam pengawasan langsung pimpinan.

Pada tataran inilah dirasakan faktor kepemimpinan dan budaya sangat berpengaruh terhadap kinerja aparat birokrasi dalam melaksanakan tugas dan fungsinya sesuai dengan visi, misi dan tujuan organisasi. Peraturan Pemerintah
Republik Indonesia No 41 Tahun 2007 tentang organisasi perangkat daerah mencetuskan kelurahan merupakan wilayah kerja lurah sebagai perangkat daerah kabupaten/kota dalam wilayah kecamatan yang berkedudukan dibawah dan bertanggung jawab kepada bupati/walikota melalui camat.

Berdasarkan

Peraturan

Pemerintah Nomor 19 Tahun 2008 tentang Kecamatan, dalam Pasal 14 ayat (1) dimana kecamatan merupakan perangkat daerah kabupaten/kota sebagai pelaksana teknis kewilayahan yang mempunyai wilayah kerja tertentu dan dipimpin oleh Camat.

Pemerintah Kabupaten Mamuju terbagi dalam 15 Kecamatan. Kecamatan merupakan suatu organisasi dalam memberikan pelayanan kepada masyarakat. Organisasi kecamatan merupakan unsur lini kewilayahan, Camat menjalankan tugas pokok sebagai unsur lini yaitu " to do, to act" artinya kegiatan Camat beserta jajarannya bersifat operasional, memberikan pelayanan langsung kepada masyarakat.

Berbagai upaya telah dilakukan oleh pemerintah untuk membentuk sosok aparat pemerintah yang ideal sesuai dengan tuntutan saat ini. Namun kenyataannya keluhan masyarakat terhadap kinerja aparat pemerintahan 
dalam melayani kerap kali mewarnai proses hubungan antara yang melayani dengan yang dilayani. Fenomena yang hampir dapat dijumpai pada berbagai instansi pemerintah, tidak terkecuali juga dijumpai di lingkungan kerja Pemerintah Kabupaten Pohuwato khususnya Kinerja Kepala Desa Dalam Pembangunan Infrastruktur Desa Sidorukun Kecamatan Randangan Kabupaten Pohuwato, Desa Sidorukun yang menjadi objek dalam penelitian ini. Atas dasar latar belakang pemikiran di atas, penulis tertarik untuk melakukan penelitian dengan judul : Kinerja Kepala Desa Dalam Pembangunan Infrastruktur Desa Sidorukun Kecamatan Randangan Kabupaten Pohuwato".

\section{KAJIAN PUSTAKA}

\section{PENGERTIAN KINERJA}

Istilah kinerja merupakan terjemahan dari performance yang sering diartikan oleh para cendekiawan sebagai "penampilan", "unjuk kerja”, atau "prestasi" (Yeremias T. Keban, 2004 : 191). Secara etimologis, kinerja adalah sebuah kata yang dalam bahasa Indonesia berasal dari kata dasar "kerja" yang menerjemahkan kata dari bahasa asing prestasi, bisa pula berarti hasil kerja. Sehingga pengertian kinerja dalam organisasi merupakan jawaban dari berhasil atau tidaknya tujuan organisasi yang telah ditetapkan

(www.wikipedia.com).

Berbeda dengan Bernardin dan Russel (1993 : 379) dalam Yeremias T. Keban (2004 : 192) mengartikan kinerja sebagai therecord of outcomes produced on a specified job function or activityduring a specified time period. Dalam definisi ini, aspek yang ditekankan oleh kedua pengarang tersebut adalah catatan tentang outcome atau hasil akhir yang diperoleh setelah suatu pekerjaan atau aktivitas dijalankan selama kurun waktu tertentu.

Dengan demikian kinerja hanya mengacu pada serangkaian hasil yang diperoleh seorang pegawai selama periode tertentu dan tidak termasuk karakteristik pribadi pegawai yang dinilai. Sedangkan Suyadi Prawirosentono (1999 : 2) mendefinisikan kinerja sebagai performance, yaitu hasil kerja yang dapat dicapai oleh seseorang atau sekelompok orang dalam suatu organisasi, sesuai dengan wewenang dan tanggung jawab masing-masing, dalam rangka upaya mencapai tujuan organisasi bersangkutan secara legal, tidak melanggar hukum dan sesuai dengan moral dan etika. Definisi kinerja organisasi yang dikemukakan oleh Bastian dalam Hessel Nogi (2005 : 175) 
sebagai gambaran mengenai tingkat pencapaian pelaksanaan tugas dalam suatu organisasi, dalam mewujudkan sasaran, tujuan, misi, dan visi organisasi tersebut. Senada dengan pendapat Bastian dalam Hessel Nogi tersebut, Encyclopedia of Public Administration and Public Policy Tahun 2003 dalam Yeremias T. Keban (2004: 193), jugamenyebutkan kinerja dapat memberikan gambaran tentangseberapa jauh organisasi mencapai hasil ketika dibandingkandengan pencapaian tujuan dan target yang telah ditetapkan.

Dari beberapa definisi di atas, dapat ditarik suatu kesimpulanbahwa kinerja merupakan suatu capaian atau hasil kerja dalamkegiatan atau aktivitas atau program yang telah direncanakansebelumnya guna mencapai tujuan serta sasaran yang telahditetapkan oleh suatu organisasi dan dilaksanakan dalam jangka waktu tertentu.

\section{FAKTOR YANG MEMPENGARUHI} KINERJA

Kinerja merupakan suatu capaian atau hasil kerja dalam kegiatan atau aktivitas atau program yang telah direncanakan sebelumnya guna mencapai tujuan serta sasaran yang telah ditetapkan oleh suatu organisasi dan dilaksanakan dalam jangka waktu tertentu yang dipengaruhi oleh beberapa faktor. Dalam Yeremias T. Keban (2004 : 203) untuk melakukan kajian secara lebih mendalam tentang faktor-faktor yang mempengaruhi efektivitas penilaian kinerja di Indonesia, maka perlu melihat beberapa faktor penting sebagai berikut :

Kejelasan tuntutan hukum atau peraturan perundangan untuk melakukan penilaian secara benar dan tepat. Dalam kenyataannya, orang menilai secara subyektif dan penuh dengan bias tetapi tidak ada suatu aturan hukum yang mengatur atau mengendaikan perbuatan tersebut.

Manajemen sumber daya manusia yang berlaku memiliki fungsi dan proses yang sangat menentukan efektivitas penilaian kinerja. Aturan main menyangkut siapa yang harus menilai, kapan menilai, kriteria apa yang digunakan dalam sistem penilaian kinerja sebenarnya diatur dalam manajemen sumber daya manusia tersebut. Dengan demikian manajemen sumber daya manusia juga merupakan kunci utama keberhasilan sistem penilaian kinerja.

Kesesuaian antara paradigma yang dianut oleh manajemen suatu organisasi dengan tujuan penilaian kinerja. Apabila paradigma yang dianut masih berorientasi pada manajemen 
klasik, maka penilaian selalu biasa kepada pengukuran tabiat atau karakter pihak yang dinilai, sehingga prestasi yang seharusnya menjadi fokus utama kurang diperhatikan.

Komitmen para pemimpin atau manajer organisasi publik terhadap pentingnya penilaian suatu kinerja. Bila mereka selalu memberikan komitmen yang tinggi terhadap efektivitas penilaian kinerja, maka para penilai yang ada dibawah otoritasnya akan selalu berusaha melakukakan penilaian secara tepat dan benar. Menurut Soesilo dalam Hessel Nogi (2005 : 180), kinerja suatu organisasi dipengaruhi adanya faktorfaktor berikut :

Struktur organisasi sebagai hubungan internal yang berkaitan dengan fungsi yang menjalankan aktivitas organisasi.

Kebijakan pengelolaan, berupa visi dan misi organisasi; Sumber daya manusia, yang berhubungan dengan kualitas karyawan untuk bekerja dan berkarya secara optimal.

Sistem informasi manajemen, yang berhubungan dengan pengelolaan data base untuk digunakan dalam mempertinggi kinerja organisasi.

Sarana dan prasarana yang dimiliki, yang berhubungan dengan penggunaan teknologi bagi penyelenggaraan organisasi pada setiap aktivitas organisasi.

Selanjutnya Yuwono dkk.dalam Hessel Nogi (2005 : 180) mengemukakan bahwa faktor-faktor yang dominan mempengaruhi kinerja suatu organisasi meliputi upaya manajemen dalam menerjemahkan dan menyelaraskan tujuan organisasi, budaya organisasi, kualitas sumber daya manusia yang dimiliki organisasi dan kepemimpinan yang efektif. Banyak faktor yang mempengaruhi kinerja organisasi baik publik maupun swasta. Secara detail Ruky dalam Hessel Nogi (2005 : 180) mengidentifikasikan faktor-faktor yang berpengaruh langsung terhadap tingkat pencapaian kinerja organisasi sebagai berikut :

Teknologi yang meliputi peralatan kerja dan metode kerja yang digunakan untuk menghasilkan produk dan jasa yang dihasilkan oleh organisasi, semakin berkualitas teknologi yang digunakan, maka akan semakin tinggi kinerja organisasi tersebut.

Kualitas input atau material yang digunakan oleh organisasi.

Kualitas lingkungan fisik yang meliputi keselamatan kerja, penataan ruangan, dan kebersihan. 
Budaya organisasi sebagai pola tingkah laku dan pola kerja yang ada dalam organisasi yang bersangkutan.

Kepemimpinan sebagai upaya untuk mengendalikan anggota organisasi agar bekerja sesuai dengan standard dan tujuan organisasi.

Pengelolaan sumber daya manusia yang meliputi aspek kompensasi, imbalan, promosi, dan lainlainnya.

Menurut Atmosoeprapto, dalam Hessel Nogi (2005 : 181) mengemukakan bahwa kinerja organisasi dipengaruhi oleh faktor internal dan faktor eksternal, secara lebih lanjut kedua faktor tersebut diuraikan sebagai berikut :

- Faktor eksternal, yang terdiri dari

Faktor politik, yaitu hal yang berhubungan dengan keseimbangan kekuasaan Negara yang berpengaruh pada keamanan dan ketertiban, yang akan mempengaruhi ketenangan organisasi untuk berkarya secara maksimal.

Faktor ekonomi, yaitu tingkat perkembangan ekonomi yang berpengaruh pada tingkat pendapatan masyarakat sebagai daya beli untuk menggerakkan sektor-sektor lainya sebagai suatu system ekonomi yang lebih besar.
Faktor sosial, yaitu orientasi nilai yang berkembang di masyarakat, yang mempengaruhi pandangan mereka terhadap etos kerja yang dibutuhkan bagi peningkatan kinerja organisasi.

- Faktor internal, yang terdiri dari : Tujuan organisasi, yaitu apa yang ingin dicapai dan apa yang ingin diproduksi oleh suatu organisasi.

Struktur organisasi, sebagai hasil desain antara fungsi yang akan dijalankan oleh unit organisasi dengan struktur formal yang ada.

Sumber Daya manusia, yaitu kualitas dan pengelolaan anggota organisasi sebagai penggerak jalanya organisasi secara keseluruhan.

Budaya Organisasi, yaitu gaya dan identitas suatu organisasi dalam pola kerja yang baku dan menjadi citra organisasi yang bersangkutan.

Dari berbagai pendapat di atas dapat disimpulkan bahwa terdapat banyak faktor yang mempengaruhi tingkat kinerja dalam suatu organisasi. Namun secara garis besarnya, faktor yang sangat dominan mempengaruhi kinerja organisasi adalah faktor internal (faktor yang datang dari dalam organisasi) dan faktor eksternal (faktor yang datang dari luar organisasi). Setiap organisasi akan mempunyai tingkat kinerja yang berbeda-beda karena pada 
hakekatnya setiap organisasi memiliki ciri atau karakteristik masing-masing sehingga permasalahan yang dihadapi juga cenderung berbeda tergantung pada faktor internal dan eksternal organisasi.

\section{PENILAIAN KINERJA}

Menurut Larry D. Stout dalam Hessel Nogi (2005 : 174) mengemukakan bahwa pengukuran atau penilaian kinerja organisasi merupakan proses mencatat dan mengukur pencapaian pelaksanaan kegiatan dalam arah pencapaian misi (missionaccomplishment) melalui hasil yang ditampilkan berupa produk, jasa ataupun suatu proses. Berbeda dengan pernyataan yang dikemukakan oleh Bastian (2001 : 330) dalam Hessel Nogi (2005 : 173) bahwa pengukuran dan pemanfaatan penilaian kinerja akan mendorong pencapaian tujuan organisasi dan akan memberikan umpan balik untuk upaya perbaikan secara terus menerus. Secara rinci, Bastian mengemukakan peranan penilaian pengukuran kinerja organisasi sebagai berikut :

Memastikan pemahaman para pelaksana dan ukuran yang digunakan untuk pencapaian prestasi.

Memastikan tercapainya skema prestasi yang disepakati. Memonitor dan mengevaluasi kinerja dengan perbandingan antara skema kerja dan pelaksanaanya.

Memberikan

penghargaan

maupun hukuman yang objektif atas prestasi pelaksanaan yang telah diukur, sesuai dengan sistem pengukuran yang telah disepakati.

Menjadikanya sebagai alat komunikasi antara bawahan dan pimpinan dalam upaya memperbaiki kinerja organisasi.

Mengidentifikasi apakah kepuasan pelanggan sudah terpenuhi. Membantu proses kegiatan organisasi.

Memastikan bahwa pengambilan keputusan telah dilakukan secara objektif. Menunjukkan peningkatan yang perlu dilakukan.

Mengungkapkan permasalahan yang terjadi, Begitu pentingnya penilaian kinerja bagi keberlangsungan organisasi dalam mencapai tujuan, maka perlu adanya indikatorindikator pengukuran kinerja yang dipakai secara tepat dalam organisasi tertentu.

Menurut Agus Dwiyanto (2006 : 49 ) penilaian kinerja birokrasi publik tidak cukup dilakukan dengan menggunakan indikator yang melekat pada birokrasi itu, seperti efisiensi dan efektivitas, tetapi juga harus dilihat dari indicator indikator yang melekat pada pengguna jasa, seperti kepuasan 
pengguna jasa, akuntabilitas dan responsivitas. Penilaian kinerja dari sisi pengguna jasa menjadi sangat penting karena birokrasi publik juga muncul karena tujuan dan misi birokrasi publik seringkali bukan hanya memiliki stakeholder yang banyak dan memiliki kepentingan yang sering berbenturan satu sama lainya menyebabkan birokrasi publik mengalami kesulitan untuk merumuskan misi yang jelas. Akibatnya, ukuran kinerja organisasi publik di mata para stakeholder juga berbeda-beda.

Dan menurut Ndraha, Taliziduha (1991: 32) Kinerja kepala desa dapat melakukan dimana :

- Mengkoordinasikan kegiatan pemberdayaan masyarakat desa

- Mengkoordinasikan upaya penyelenggaraan ketentraman dan ketertiban umum;

- Mengkoordinasikan penerapan dan penegakan peraturan perundang-undangan;

\section{PEMBANGUNAN INFRASTRUKTUR DESA}

Definisi pembangunan merupakan upaya yang sistematik dan berkesinambungan/berkelanjutan untuk menciptakan keadaan yang dapat menyediakan berbagai alternative yang sah bagi pencapaian aspirasi setiap warga yang paling humanistik (Anwar
2005:34, Dalam Hubungan Dengan Konsep Pembangunan Daerah).

Taliziduhu Ndraha dalam Soebroto (2001:45) memberikan beberapa kriteria yang terdapat dalam pembangunan masyarakat desa, yaitu :

Adanya partisipasi aktif masyarakat dalam pembagunan. Adanya rasa tanggungjawab masyarakat terhadap pembangunan.

Kemampuan masyarakat desa untuk berkembang telah dapat ditingkatkan. Prasarana fisik telah dapat dibangun dan dipelihara.

Lingkungan hidup yang serasi telah dapat dibangun dan dipelihara. Sedangkan Mely G. Tan dan Koentjaraningrat dalam Soebroto (2001: 60), memberikan beberapa hal yang dapat digunakan untuk menilai keberhasilan pembangunan masyarakat desa, yaitu :

Hasil usaha pembaharuan tersebut harus dapat dilihat secara konkrit dalam waktu yang singkat. Usaha pembaharuan tersebut harus dapat bermanfaat bagi masyarakat yang bersangkutan. Usaha-usaha tersebut tidak boleh bertentangan dengan sistem nilai budaya dan norma-norma yang masih berlaku di dalam masyarakat desa.

Sejalan dengan pemaparan diatas, dalam pelasanaan pembagunan yang 
direncanakan oleh pemerintah; partisipasi masyarakat merupakan hal yang sangat mempengaruhi keberhasilan proses pembangunan itu sendiri. Karena masyarakatlah yang mengetahui secara obyektif kebutuhan mereka.

Salah satu titik berat bagi pembangunan nasional adalah wilayah pedesaan dengan berbagai kenyamanan dan daya tarik tersendiri Kemiskinan dan ketidak mampuan masyarakat pedesaan merupakan bagian yang tidak terpisahkan dengan kehidupan mereka. Hal ini merupakan salah satu kegagalan kebijakan pemerintah dimasa lalu karena seringkali kebijakan yang ditempuh tidak sesuai dengan kondisi ekosistim wilayah, keinginan serta nilai-nilai kehidupan yang dianut oleh masyarakat. Kebijakan pemerintah tersebut hanya didasarkan kepada tujuan meningkatkan kapital dan kepentingan segolongan tertentu saja yang merugikan golongan masyarakat yang lain, tidak memperhatikan keberagaman wilayah yang ada serta tidak sesuai dengan kebutuhan daerah. Seharusnya keberagaman potensi wilayah baik kondisi biofisik wilayah, kemampuan sumberdaya alam, pertumbuhan penduduk, dan akses ke pasar yang berbeda menghendaki perlakuan ataupun kebijakan yang berbeda pula yang sesuai dengan karakteristik yang dimilikinya. Kesalahan dalam pengaturan dan perancangan program-program pembangunan menyebabkan kegagalan proses pembangunan itu sendiri.

Keragaman wilayah pedesaan di Indonesia tergantung kepada tipologinya yang bervariasi, yang oleh Anwar (2005 :37), kebijakan pertanian dan pedesaan tidak dapat dilakukan secara seragam untuk semua keadaan wilayah yang masing-masing memiliki kekhasan dan sifat-sifat khusus yang berbeda satu dengan yang lain, sehingga setiap kebijakan harus memperhatikan kondisi perkembangan dari wilayah yang bersangkutan yang secara konseptual tergantung kepada akses pasar dan biaya-biaya transaksi.

Kesenjangan spasial yang terjadi antar wilayah perkotaan yang bercorak industri dan jasa dengan wilayah pedesaan yang di dominasi oleh sektor pertanian. Maka diperlukan terobosan dalam menyeimbangkan pembangunan yang berdampak pada pembangunan infrastruktur (fisik) desa, dan perekonomian rakyat pedesaan (non fisik).

Untuk itu Wresniwiro (2007:45), mengemukakan suatu konsep pembangunan untuk mengurangi ketimpangan spasial tersebut dengan 
menyeimbangkan pembangunan-kota yang dilakukan secara terpadu. Keseimbangan spasial tersebut dapat tercapai apabila dalam perencanaan pembangunan pedesaan memperhatikan berbagai faktor yang terkait dan pembangunan diarahkan untuk mencapai tujuan: (1)pemerataan, (2) pertumbuhan, (3) keterkaitan,

keberimbangan, (5) kemandirian, dan (6) keberlanjutan.

Keterpaduan

pembangunan tersebut dalam perencanaan dan proses pembangunan akan meningkatkan produktifitas daerah pedesaan dengan berpegang pada prinsip pembangunan yang berkelanjutan dan tetap menjunjung tinggi nilai-nilai keutamaan yang dianut masyarakat. Pembangunan bukanlah kegiatan pada ruang kosong tetapi kegiatan yang dilakukan pada tempat dimana sejumlah penduduk yang memiliki nilai-nilai tertentu menjadi obyek dan sekaligus sebagai subyek pembangunan.

Sehingga nilai-nilai keutamaan yang dianut masyarakat, organisasi swadaya dan pengelolaan sumberdaya yang bersifat swadaya hendaknya menjadi landasan penyelenggaraan pembangunan.

Pendekatan pembangunan ke wilayah pedesaan harus dilakukan tidak hanya kegiatan fisik saja (infrastruktur), melainkan yang lebih penting sebagai entry point-nya adalah kegiatan ekonomi (non fisik) berdasarkan pada potensi unggulan dimasing-masing wilayah, sehingga kesejahteraan rakyat pedesaan dapat segera terwujud.

Sebab kunci dari pembangunan yaitu kurangnya masyarakat yang masih tergolong kurang sejahtera dibidang perekonomian, dimana hal itu dikategorikan sebagai rakyat miskin. Dikarenakan prekenomian rakyat yang tidak memenuhi kebutuhan hidup dari segi sandang dan pangan. Dimana sebagian orang terkadang pembangunan diartikan adanya gedung megah. Padahal pembangunan itu ada dua segi yaitu pembangunan fisik dan non fisik. (Wresniwiro, 2007:58).

\section{METODE PENELITIAN}

\section{Teknik Pengumpulan Data}

Menurut Husaini Usman dan Purnomo Setiady (2001:54-73), bahwa dalam pengumpulan data terdiri dari, "Observasi, wawancara, angket dan dokumentasi. Melihat hal itu sehingga peneliti menggunakan dalam teknik pengumpulan data penelitian ini menggunakan beberapa cara anatara lain: 
1. Observasi yaitu, untuk melihat secara langsung dan mencari informasi yang ada kaitanya dengan penelitian.

2. Wawancara yaitu, untuk memperoleh informasi secara langsung dari responden melalui proses komunikasi dua arah.

3. Angket yaitu, daftar pertanyaan dari peneliti kepada responden baik secara langsung atau tidak langsung.

4. Dokumentasi yaitu, bentuk dokumen-dokumen yang ada dan berkaitan didalam penelitian ini. Untuk mendapatkan data yang lebih baik dalam arti mendekati kenyataan (objektif) sudah tentu diperlukan suatu instrumen atau alat pengumpulan data yang baik dan lebih penting lagi adanya alat ukur yang valid dan handal (reliabel). Dan untuk itu dapat menyakini bahwa instrumen atau alat ukur yang di gunakan itu valid dan handal, maka instrumen tersebut sebelum digunakan harus di uji secara kualitatif dan menghasilkan data yang obyektif.

\section{Teknik Analisis Data}

Data Yang didapatkan dilapangan akan dianalisis secara kulitatif. Analisis kualitatif digunakan untuk menggambarkan upaya yang dilakukan berupa Kinerja Kepala Desa Dalam Pembangunan Infrastruktur Desa Sidorukun Kecamatan Randangan Kabupaten Pohuwato, serta faktorfaktor penghambat Kinerja Kepala Desa Dalam Pembangunan Infrastruktur Desa Sidorukun Kecamatan Randangan Kabupaten Pohuwato.

\section{Pembahasan}

Kinerja Kepala Desa Dalam Pembangunan Infrastruktur Desa Sidorukun Kecamatan Randangan Kabupaten Pohuwato

Kinerja Kepala Desa Dalam penyelenggaraan pemerintahan tertuang dalam danmerupakan yang menjadi indikator penelitian ini antara lain: Mengkoordinasikan kegiatan pemberdayaan masyarakat; Mengkoordinasikan upaya penyelenggaraan ketentraman dan ketertiban umum, Mengkoordinasikan penerapan dan penegakan peraturan perundang-undangan. Pembangunan infrastruktur desa indikatornya,adanya partisipasi aktif masyarakat dalam pembagunan, adanya rasa tanggungjawab masyarakat terhadap pembangunan dan kemampuan masyarakat desa untuk berkembang telah dapat ditingkatkan.

Adapun cara penyusunan program, dengan mengikuti beberapa langkah 
berikut: (1) mengidentifikasi masalah yang harus diintervensi, (2) menegaskan tujuan yang hendak dicapai dan (3) merancang struktur proses implementasi. Di pihak lain, untuk mengimplementasikan kebijakan, secara rinci. Casley dan Kumar, menunjukkan sebuah metode dengan enam langkah sebagai berikut :

1. Identifikasi masalah. Batasilah masalah yang akan dipecahkan atau dikelola dan pisahkan masalah dari gejala yang mendukungnya. Rumuskan sebuah hipotesis.

2. Tentukan faktor-faktor yang menjadikan adanya masalah tersebut. Kumpulkan data kuantitatif maupun kualitatif yang memperkuat hipotesis.

3. Kajilah hambatan dalam pembuatan keputusan. Analisislah situasi politik dan organisasi yang dahulu mempengaruhi pembuatan kebijakan.

Pertimbangkan berbagai variabel seperti komposisi staf, moral dan kemampuan staf, tekanan politik, kepekaan budaya, kemauan penduduk dan efektivitas manajemen.

4. Kembangkan solusi-solusi alternatif.
5. Perkirakan solusi yang paling layak. Tentukan kriteria dengan jelas dan terterapkan (aplicable) untuk menguji kelebihan dan kekurangan setiap solusi alternatif.

6. Pantaulah terus umpanbalik dari tindakan yang telah dilakukan guna menentukan tindakan yang perlu diambil berikutnya.

Evaluasi publik merupakan suatu kondisi dinamis yang berhubungan dengan produk, jasa manusia, proses dan lingkungan yang memenuhi atau melebihi harapan. Evaluasi publik akan menyentuh masalah kualitas layanan yang diberikan oleh organisasi publik pada masyarakat sebagai pelanggan. Kualitas pelayanan umumnya berfokus pada masyarakat, sehingga produk pelayanan didesain, diproduksi serta diberikan untuk memenuhi keinginan dan kepuasan pelanggan. Dan Effendi dalam Widodo, (2001:21). Birokrasi publik harus dapat memberikan layanan publik yang lebih profesional, efektif, sederhana, transparan, terbuka, tepat waktu, responsif dan adaptif serta sekaligus dapat membangun kualitas manusia dalam arti meningkatkan kapasitas individu dan masyarakat untuk secara aktif menentukan masa depannya sendiri. 
Arah pembangunan kualitas manusia tadi adalah memberdayakan kapasitas manusia dalam arti menciptakan kondisi yang memungkinkan setiap anggota masyarakat mengembangkan kemampuan dan krativitasnya untuk mengatur dan menentukan masa depannya sendiri.

Goetsch dan Davis dalam Tjiptono, (1996:56) mendefinisikan kualitas merupakan suatu kondisi dinamis yang berhubungan dengan produk, jasa, manusia, proses dan lingkungan yang memenuhi atau melebihi harapan. Konteks daerah, penyelenggaraan pelayanan publik Mengacu pada UU No 32 Tahun 2004 tentang pemerintahan daerah pasal 22 haruslah bisa diwujudkan di dalam rencana kerja pemerintahan daerah karena merupakan kewajiban daerah yang nantinya akan dijabarkan dalam bentuk APBD. Pelayanan publik dimulai dari akte kelahiran, surat idenstitas diri, pelayanan kesehatan dasar, pendidikan , keamanan dan ketertiban, hak-hak untuk hidup secara adil, surat menyurat merupakan kebutuhan dasar.

Yang menjadi persoalan ialah seringkali pada saat kita membutuhkan layanan yang cepat, yang kita dapatkan malah sebaliknya. Lamban, berbelit-belit dan dalam situasi seperti inilah yang membuat kita merasakan bahwa Kepemimpinan Camat Dalam Penyelenggaraan PelayananPublik itu buruk dan tidak baik terkait permasalahan kebutuhan pelayanan publik.

\section{Kinerja Kepala Desa}

Kinerja kepala desa sebenarnya yang menjadi persoalan disini ada pada pelaksananya yakni para birokrat itu sendiri artinya bahwa dalam hal pelaksanaan sumber daya yang kurang memadai mengisi ditataran birokrat untuk pencapaian tugas administartif. Secara akademik,kinerja Kepala Desa Dalam Pembangunan Infrastruktur Desa Sidorukun Kecamatan Randangan Kabupaten Pohuwato adalah penyelesai masalah/ a world of solution namun dalam prakteknya ini bagian dari masalah/ parts of the problems, hal ini kemudian yang menyebabkan malasnya masyarakat berurusan dengan birokrasi/pemerintahan.

Beberapa langkah yang harus diambil oleh pihak pemerintah adalah mengambil langkah strategis untuk dapat mengefektifkan kembali pelayanan yang ideal dengan mengambil langkah dimana Kinerja Kepala Desa Sidorukun:

a) Mengkoordinasikan kegiatan pemberdayaan masyarakat desa. 
Salah satu urusan di kantor Kepala Desa Sidorukun, berdasarkan uraian dari narasumber dan beberapa masukan peserta rapat maka rapat merumuskan, pengamalan nilai-nilai luhur Pancasila dan budaya bangsa, fundamentalisme yang ekstrim, lunturnya sikap dan kesatuan bangsa serta kegotong-royongan di masyarakat merupakan embrio yang dapat mendorong terjadinya potensi konflik masyarakat. Bagaimanakah strategi pembinaan yang tepat, efektif dan efisien agar masyarakat mampu mencegah terjadinya gangguan di lingkungan Kepala Desa Sidorukun.

Masih kurang kepedulian warga masyarakat untuk menyampaikan informasi potensi gangguan kamtibmas sehingga penanganan antisipasi gangguan di lingkungan Kepala Desa Sidorukun menjadi lambat. Bagaimanakah kebijakan pelayanan publik terbaik untuk menjawab ketidakpuasan masyarakat salah satu bentuk ketegasan pemerintah adalah komoditas regulasi atau aturan hukum. Komoditas regulasi/aturan hukum seharusnya mampu mengantisipasi segala bentuk pelanggaran sehingga tercipta kondisi masyarakat terlindungi, aman dan tertib. Lemahnya komoditas regulasi secara langsung maupun tidak langsung memberikan celah bagi kelompok-kelompok yang tidak menghargai hak-hak dan keberagaman kehidupan serta persatuan bangsa, sehingga memicu kepada masyarakat untuk bertindak dengan caranya sendiri yang pada hakekatnya justru melanggar hukum dan mengganggu ketertiban. Terkait dengan perkembangan kondisi dan situasi saat ini, bagaimanakah penegakan aturan hukum yang tepat.

Ketidakdewasaan dunia usaha dan masyarakat dalam pemenuhan hak dan kewajiban hal ini diwujudkan dengan aksi-aksi yang juga berpotensi menimbulkan kerawanan gangguan Kamtibmas di masyarakat. Bagaimanakah upaya yang perlu dilakukan untuk meningkatkan kesadaran bermasyarakat di kalangan masyarakat dan dunia usaha. Lemahnya nilai toleransi dan saling menghargai antar sesama anggota masyarakat mencerminkan belum dewasanya kita dalam bermasyarakat. Hal ini tercermin adanya kelompok kelompok radikal yang memaksakan kehendak di masyarakat. Toleransi dan kegotong-royongan terkadang baru muncul apabila baru ada bencana. Bagaimana upaya agar komponen aparat di daerah dari di lingkungan Kecamatan Randangan Kabupaten Pohuwato dapat lebih 
berperan dalam meningkatkan perlindungan, kepedulian, toleransi dan partisipasi masyarakat dalam segala situasi dan kondisi.

b. Mengkoordinasikan upaya penyelenggaraan ketentraman dan ketertiban umum.

Kepala Desa Sidorukun dalam mengoordinasikan upaya peyelenggaraan ketenteraman dan ketertiban umum meliputi:

- Melakukan koordinasi dengan Kepolisian Negara Republik Indonesia dan/atau Tentara Nasional Indonesia mengenai program dan kegiatan penyelenggaraan ketenteraman dan ketertiban umum di wilayah kecamatan;

- Melakukan koordinasi dengan pemuka agama yang berada di wilayah kerja kecamatan untuk mewujudkan ketenteraman dan ketertiban umum masyarakat di wilayah kecamatan; dan

- Melaporkan pelaksanaan pembinaan ketenteraman dan ketertiban kepada bupati/walikota.

Tujuan dalam penyelenggaraan ketentraman dan ketertiban umum merupakan harapan yang dikehendaki dari setiap pemerintah daerah, keadaan masyarakat yang tentram dan kondusif. semua ini merupakan pengharapan dimana pemerintah, pemerintah daerah, masyarakat dapat melaksanakan segala kegiatannya dengan tentram, tertib dan teratur. Penyelenggaraan ketentraman dan ketertiban umum ini di definisikan bagaimana langkah-langkah yang harus dilakukan pemerintah daerah untuk mencapai tujuannya, keadaan yang dimana tuntutan, larangan, pemaksaan yang diberikan kepada masyarakat maupun kepada penyelenggara pemerintah daerah itu sendiri. Untuk mencapai tujuan tersebut tentulah adanya keselarasan antara pengenalan terhadap apa dan mau kemana atau juga dapat dikatakan tepat sasaran.

Usaha dari pemerintah daerah dalam mewujudkan keadaan tentram dan ketertiban umum dapat dibagi dalam tahap perencanaan awal yang matang, pelaksanaan yang berkesinambungan sampai pada pengukuran atau yang menentukan arah kebijakan selanjutnya. Adapun hasil wawancara peneliti dengan salah satu aparat yang berada di Kantor Desa Sidorukun mengatakan bahwa:

“Upaya pemerintah desa dalam upaya penyelenggaraan ketentraman dan ketertiban umum sudah cukup optimal dengan mengadakan pos kambling di 
setiap dusun dan aparat pengamanan (hansip)" (Wawancara 17 november 2014).

Namun berbeda halnya dengan yang dirasakan oleh salah seorang warga bernama Ali Najib Tantu mengatakan : "Kami masih merasa kurang nyaman dan aman karena aparat pengamanan tidak berjaga selama 24 jam, tetapi di satu sisi kami merasa tentram karena masyarakat yang ada didusun kami hidup dengan harmonis, damai dan saling menghormati, menjaga satu dengan yang lain". (Wawancara 19 november 2014).

Mengkoordinasikan penerapan dan penegakan peraturan perundangundangan. Kepala Desa Sidorukun dalam mengkoordinasikan penerapan dan penegakan peraturan perundangundangan meliputi:

- Melakukan koordinasi dengan satuan kerja perangkat daerah yang tugas dan fungsinya di bidang penerapan peraturan perundang-undangan;

- Melakukan koordinasi dengan satuan kerja perangkat daerah yang tugas dan fungsinya di bidang penegakan peraturan perundang-undangan dan/atau Kepolisian Negara Republik Indonesia; dan
- Melaporkan pelaksanaan penerapan dan penegakan peraturan perundang-undangan di wilayah kecamatan kepada bupati/walikota.

Kepala Desa Sidorukun berkedudukan sebagai koordinator penyelenggaraan pemerintahan di wilayah desa, " Kepala Desa Sidorukun atau sebutan lain adalah pemimpin dan koordinator penyelenggaraan pemerintahan di wilayah kerja desa yang dalam pelaksanaan tugasnya memperoleh pelimpahan kewenangan pemerintahan dari Bupati/Walikota untuk menangani sebagian urusan otonomi daerah, dan menyelenggarakan tugas umum pemerintahan".

Bedasarkan hasil wawancara peneliti dengan salah seorang aparat yang ada mengatakan bahwa : "Upaya dalam mengkoordinasikan penerapan dan penegakan peraturan perundangundangan sudah dilaksanakan dengan maksimal, salah satu contoh yang kami lakukan ialah memberikan sosialisasi kepada masyarakat dan juga penempelan poster- poster menyangkut peraturan peraturan daerah".

\section{Pembangunan infrastruktur desa.}

Salah satu titik berat bagi pembangunan nasional adalah wilayah pedesaan dengan berbagai kenyamanan 
dan daya tarik tersendiri Kemiskinan dan ketidak mampuan masyarakat pedesaan merupakan bagian yang tidak terpisahkan dengan kehidupan mereka. Hal ini merupakan salah satu kegagalan kebijakan pemerintah dimasa lalu karena seringkali kebijakan yang ditempuh tidak sesuai dengan kondisi ekosistim wilayah, keinginan serta nilai-nilai kehidupan yang dianut oleh masyarakat. Adapun indikator dari pembangunan infrastruktur desa adalah sebagai berikut:

\section{Adanya partisipasi aktif masyarakat} dalam pembagunan

Keberhasilan suatu proses pembangunan tidak dapat dilepaskan dari adanya partisipasi anggota masyrakatnya, baik sebagai kesatuan sistem maupun sebagai individu yang merupakan bagian yang sangat integral yang sangat penting dalam proses dinamika pembangunan, karena secara prinsip pembangunan ditunjukkan guna mewujudkan masyarakat yang sejahtera. Oleh sebab itu tanggung jawab berhasil tidaknya pembangunan tidak saja ditangan pemerintah tetapi juga ditangan masyarakat.

Oleh karena itu kesadaran dan partisipasi aktif dari masyarakat merupakan salah satu kunci keberhasilan pembangunan, dalam hal ini mencapai target pembangunan perlu ditunjukkan oleh kebijaksanaan pemerintah.

Sehubungan dengan itu didapat dikatakan bahwa pembangunan yang sedang dalam proses ditentukan oleh besar kecilnya partisipasi masyarakat yaitu :

a. Partisipasi sebagai titik awal perubahan.

b. Partisipasi dalam memperhatikan, menyerap dan memberi tanggapan terhadap informasi.

c. Partisipasi dalam perencanaan.

d. Partisipasi dalam melaksanaan operasional.

e. Partisipasi dalam menerima dan mengembangkan hasil pembangunan.

f. Partisipasi dalam menilai pembangunan.

Melihat bentuk partisipasi yang dikemukakan di atas, bagi masyarakat desa Sidorukun kecamatan Randangan dengan corak kehidupannya untuk mencapai sukses pembangunan hendaknya lebih mengetahui kemampuan dan keadaan nyata dengan memperhatikan aspek-aspek pokok yang berkaitan dengan pembangunan. Hal ini sesuai dengan hasil wawancara bersama Pak Hasbi yakni seorang warga desa Sidorukun kecamatan Randangan yang mengatakan bahwa : "Tidak semua program pembangunan yang ada bisa 
terlaksana di kecamatan randangan, pembangunan desa Sidorukun kecamatan Randangantetap meperhatikan kondisi masyarakat, lingkungan, dan manfaat dari pembangunan yang akan di laksnaka, selain itu tidak semua pembangunan yang ada, kita 'Masyarakat' bisa berpartisipasi aktif, karena memang harus melihat apakah pembangunan ini di tujukan untuk kami atau tidak " (wawancara tanggal 30 November 2014). Adapun bentuk partisipasi masyarakat tersebut yang secara umum mewarnai masyarakat ikut berpartisipasi dalam pembangunan, partisipasi tersebut apabila diklasifikasikan secara ideal, maka menurut hemat penulis ada empat aspek yang bentuk ideal partisipasi masyarakat desa Sidorukun kecamatan Randangan dalam pembangunan yaitu partisipasi dalam bentuk ide/pemikiran (non fisik), uang (dana), materi (barang), dan partisipasi secara langsung (tenaga/fisik). Keempat aspek tersebut dapat dilihat melalui serangkaian uraian hasil penelitian ini. Desa Sidorukun menyelenggarakan Musrenbang Desa pada tanggal 22 november 2014, yang dihadiri oleh 60 Orang terdiri dari para Ketua RW, organisasi masyarakat, LPMD, Palmas, tokoh masyarakat, tokoh pemuda dan
PKK. Masyarakat yang diundang cukup antusias dalam mengikuti proses perencanaan pembangunan mereka merasa lebih dihargai sebagai anggota masyarakat, karena dikutsertakan dalam proses perencanaan pembangunan. seperti yang diutarakan oleh salah seorang anggota PKK desa tetangga sebagai berikut ini: " Kami merasa lebih diperhatikan dan diorangkan, jadi saya merasa senang sekali. Kalau usulan ini bisa gol saya nanti pasti akan mendukungnya". (wawancara tanggal 22 november 2014).

Hal yang senada juga disampaikan oleh peserta yang lain, berikut ini: "Kita merasa plong karena usulan-usulan yang telah kita rumuskan di tingkat dusun bisa masuk menjadi agenda pembangunan Desa Sidorukun harapan kami selanjutnya adalah bahwa program yang diusulkan tersebut bisa disetujui dan dianggarkan sampai tingkat Kabupaten". (wawancara tanggal 22 november 2014).

Dari pernyataan di atas terbukti bahwa sebenarnya untuk sebagian besar masyarakat mengharap dilibatkan di dalam proses perencanaan pembangunan, namun karena kurangnya sosialisasi tentang perencanaan pembangunan menyebabkan mereka tidak hadir dalam proses perencanaan pembangunan (musrenbang). Kepala 
Jurnal Politik dan Sosial Kemasyarakatan

Vol 11 No 3 (2019) : Desember 2019

Desa Sidorukun berusaha untuk dapat melibatkan masyarakat dalam setiap tahap proses perencanaan pembangunan tahun ini. Proses perencanaan pembangunan diselenggarakan selama sehari dari jam 08.00 sampai jam 16.30. Berikut petikan pernyataannya:

"Saya usahakan untuk proses perencanaan pembangunan kali ini sedapat mungkin bisa melibatkan masyarakat secara keseluruhan, namun karena kesibukan dan keterbatasan ruang maka tidak seluruhnya saya undang, toh aspirasi mereka sudah ditampung dalam list daftar prioritas kegiatan RT/RW, saya yakin mereka memaklumi." (Wawancara 11 November 2014).

Sedangkan proses perencanaan pembangunan di Desa Sidorukun berlangsung selama 2 jam 38 menit yakni dari jam 13.52 sampai dengan jam 16.30, pada tanggal 23 novenber 2014 yang dihadiri oleh 31 Orang peserta terdiri dari para ketua RW, Ketua LPM, Ketua Palmas (Pelayanan Kesehatan Masyarakat), dengan mekanisme sebagai berikut:

1. Tahap Persiapan, terdiri dari kegiatan rembug warga tingkat dusun yang menghasilkan daftar prioritas kegiatan yang disampaikan kepada Desa, penetapaan tim penyelenggara musrenbang Kelurahan yang bertugas menyusun jadwal, agenda, mengundang calon peserta dan menyiapkan peralatan, bahan dan materi.

2. Tahap pelaksanaan, terdiri dari:

a. Pembukaan acara oleh Sekretaris Desa Sidorukun.

b. Pemaparan kepala Desa Sidorukun, tentang deadline penyelenggaraan musrenbang kelurahan.

c. Pemaparan Kasi Pemerintahan, tentang hasil musrenbang dusun/rembug tingkat dusun.

3. Keluaran

Menetapkan 4 Orang delegasi untuk mengikuti musrenbang tingkat Kecamatan. Berdasarkan mekanisme di atas, belum ada agenda pembahasan kegiatan yang diusulkan oleh masingmasing dusun untuk ditetapkan menjadi daftar prioritas kegiatan yang akan disampaikan ke Kecamatan. Begitu pun dengan Desa Sidorukun proses perencanaan pembangunan tidak mengagendakan penetapan daftar kegiatan yang akan diusulkan ke tingkat Kecamatan, sehingga daftar tersebut dibuat oleh pihak desa tanpa melibatkan peserta yang hadir dalam musrenbang. 
Adanya rasa tanggungjawab masyarakat terhadap pembangunan

Adanya rasa tanggungjawab masyarakat terhadap pembangunan tidak lepas dari anggaran atau Dana. Dana merupakan salah satu penggerak utama yang mene ntukan dalam penyelengaraan pembangunan, tetapi yang tidak kalah pentingnya adalah sumbangan masyarakat dalam bentuk materi (barang). Tidak semuanya masyarakat menyumbang dalam bentuk uang tetapi ada juga masyarakat yang berpartisipasi dalam bentuk materi (barang), bahkan ada masyarkat yang menyumbangkan kedua-duanya (uang dan materi). Hal ini didasari karena adanya rasa tanggung jawab masyarakat terhadap pembangunan yang dilaksanakan di daerahnya, khususnya desa Sidorukun.

Sumbangan materi (barang) biasanya dilakukan secara langsung dimana sumbangan materi (barang) tersebut diperuntukkan untuk pembangunan yang bersifat fisik seperti pembangunan masjid, jembatan, perbaikan jalanan dan sarana-sarana umum lainnya.

Tingkat partisipasi masyarakat dalam bentuk materi (barang) berada dalam kategori rendah, karena berdasarkan wawancara langsung dengan informan mengatakan bahwa masyarakat lebih banyak menyumbangkan dalam bentuk uang (dana). Alasan lain yang diungkapkan informan bahwa untuk menyumbang dalam bentuk materi prosedurnya agak rumit dan menyita waktu dan tenaga. Hal ini sesuai dengan yang di ungkapkan oleh Kepala Desa Sidorukun.yang mengatakan bahwa;

"Jarang sekali masyarakat yang memberikan sumbangan dalam bentuk materi. Mereka lebih memilih memberikan uang, karena mereka tidak mau repot. Namun ada juga yang memang memberikan materi seperti kayu, pasir, batu dan lain-lain." (wawancara tanggal 17 November 2014) Berdasarkan data yang diperoleh dari beberapa informan diatas bahwa barang yang disumbangkan dalam pembangunan, biasanya dalam bentuk material seperti pasir, batu, kayu papan dan kayu balok .

\section{Kemampuan masyarakat desa untuk berkembang telah dapat ditingkatkan}

Kemampuan masyarakat desa untuk berkembang telah dapat ditingkatkan dilihat pada setiap proses pembangunan suatu masyarakat mutlak bagi tercapainya tujuan pembangunan. Idealnya adalah merupakan iuaran dan partisipasi mesyarakat yaitu usaha untuk 
menumbuhkan kemampuan masyarakat untuk berpartisipasi, sehingga proses pembangunan dapat meringangkan beban pemerintah desa dan akhirnya pembangunan itu dapat dirasakan secara adil dan merata.

Demikian pula secara sederhana dapat diketahui bahwa masyarakat hanya akan terlihat dalam aktifitas selanjutnya apabila mereka merasa ikut ambil bagian dalam menentukan apa yang akan dilaksanakan pemerintah Desa. Hal penting yang perlu diperhatikan adalah kesediaan untuk membantu berhasilnya setiap program pembangunan di desa sesuai kemampuan yang dimiliki setiap orang/anggota masyarakat tanpa berarti mengorbankan kepentingan diri sendiri sudah dikategorikan ke dalam pengertian partisipasi. Oleh sebab itu dalam partisipasi Non Fisik masyarakat sangat mendasar sekali, terutama dalam tahap perencanaan dan pengambilan keputusan. Karena keikutsertaan ini adalah sebgai ukuran tingkat partisipasi masyarakat. Semakin besar kemampuan untuk menentukan nasib sendiri semakin besar partisipasi dalam pembangunan. Hal ini sesuai dengan uraian Camat Randangan, mengemukakan bahwa:

"Pembangunan yang dilihat pada kemampuan masyarakat desa untuk berkembang telah dapat ditingkatkan di desa Sidorukun kecamatan Randanagan sebagian besar adalah hasil musrembang yang telah di laksanakan bersama masyarakat. Secara tidak langsung ide dan gagasan pembangunan awalnya merupakan bagian dari partisipasi masyarakat kecamatan Randangan, jadi mereka 'masyarakat' memang sudah berpartisipasi" (wawancara tanggal 15 November 2014)

Keberhasilan suatu pembangunan, bagaimana bentuk dan hasilnya tidak dapat dilepaskan oleh adanya putusan-putusan yaitu melalui tahapan-tahapan pengambilan keputusan. Pada tahap-tahap tertentu keterlibatan masyarakat sangatlah di butuhkan mengingat ide-ide atau pemikiran dapat menjadi bahan pertimbangan.

Partisipasi masyarakat dalam bentuk non fisik adalah bagaimana masyarakat terlibat dalam memberikan buah pikirannya dalam proses pembangunan. Partisipasi dapat diwujudkan pada berbagai macam kesempatan, seperti melalui pertemuan/rapat, melalui surat/saran dan tanggapan terhadap proses pembangunan.

$$
\text { Penyaluran ide-ide dan }
$$
sumbangan pemikirannya dapat 
disalurkan lewat lembaga-lembaga formal yang ada. Untuk mengetahui partisipasi masyarakat di Desa Sidorukun dalam pembangunan dengan bentuk Ide/Pemikiran, maka dapat dilihat pada keikutsertaan dalam mengikuti rapat-rapat dan keaktifan dalam memberikan pendapat dan saran dalam pertemuan.

Kemampuan masyarakat desa sidorukun untiuk berkembang telah dapat ditingkatkan di lihat pula pada menentukan gagal tidaknya suatu program atau proyek. Pada tahap pelaksanaan pembangunan terdapat beberapa jenis kegiatan yang memungkinkan masyarakat dapat ikut terlibat dan ambil bagian terutama menyangkut pelaksanaan pekerjaan karena pada bagian ini masyarakat memiliki kesempatan untuk ikut terlibat memberikan dukungan, motivasi atau semangat, mengorbankan tenaga, waktu dan material. Untuk mengkaji berapa besar tingkat partisipasi masyarakat dalam pelaksanaan pembangunan maka perlu mengidentifikasi jenis kegiatan yang berhubungan dengan kegiatan pelaksanaan sebagai indikator pengukuran tingkat partisipasi terdiri dari: (1) upaya yaitu dorongan atau semangat yang terkandung dalam diri masyarakat untuk mendukung program atau memiliki sifat ajakan kepada masyarakat lain, tumbuh rasa memiliki; (2) kemauan masyarakat untuk ikut ambil bagian dalam setiap jenis kegiatan baik dalam proses sosialisasi maupun proses pelaksanaan kegiatan; kesediaan dan kemampuan masyarakat untuk berkontribusi sumber daya baik tenaga, waktu, material, uang serta kehadiran dan keatifan masyarakat untuk menerima informasi. Untuk menggali data tentang seberapa jauh tingkat partisipasi masyarakat dalam pelaksanaan pembangunan di Desa Sidorukun maka aspek tersebut.

Faktor- faktor penghambat Kinerja Kepala Desa Dalam Pembangunan Infrastruktur Desa Sidorukun Kecamatan Randangan Kabupaten Pohuwato.

Sebagaimana diketahui bahwa pembangunan tidak hanya merupakan usaha pemerintah semata atau masyarakat saja, akan tetapi suatu kegiatan bersama yang hasilnya diharapkan dapat memberikan kemakmuran dan kesejahteraan bagi seluruh lapisan masyarakat. Keberhasilan pembangunan desa Sidorukun merupakan cermin dari keberhasilan pembangunan nasional, karena itu titik berat pembangunan 
nasional diletakkan pada pembangunan kecamatan.

Apabila pembangunan tersebut dilaksanakan diwilayah kecamatan, maka sudah jelas bahwa partisipasi masyarakat kecamatanlah yang menjadi kunci keberhasilannya. Namun demikian peran serta masyarakat dalam proses pembangunan tentunya banyak faktor yang mempengaruhi tingkat keterlibatannya dalam pembangunan, menurut hemat penulis faktor yang mempengaruhi peran serta masyarakat dalam pembangunan di Desa Sidorukun Kecamatan Randangana dalah faktor intern yang meliputi kesadaran, pendidikan dan penghasilan/pendapatan. Sedangkan faktor ekstern meliputi kepemimpinan pemerintah dan peralatan/fasilitas.

\section{Faktor Intern yang meliputi :}

Faktor Kesadaran / Kemauan Keikutsertaan dalam suatu kegiatan pembangunan bukan timbul begitu saja akan tetapi karena adanya yang mendorongnya untuk berpartisipasi. Salah satu diantaranya adalah faktor kesadaran masyarakat itu sendiri. Apabila warga masyarakat sudah sadar mengenai arti pentingnya pembangunan itu, maka jelas mereka juga akan lebih banyak melibatkan diri didalamnya. Hal ini dimaksudkan agar apa yang menjadi cita-cita pembangunan dapat tercapai yakni memberikan hidup sejahtera kepada semua warga masyarakat, demikian pula halnya dengan warga masyarakat di Desa Sidorukun Kecamatan Randangan yang merupakan lokasi penelitian ini.

Alasan informan memberikan jawaban faktor kesadaran pribadi yang merupakan pendorong masyarakat untuk partisipasi dalam pembangunan karena adanya suatu kepedulian atau kesadaran untuk ikut terlibat baik secara langsung maupun tidak langsung dalam pembangunan tersebut. Sesuai dengan hasil wawancara yakni menggambarkan bahwa:

“Alasan kami ikut berpartisipasi karena kami masih punya rasa solidaritas yang tinggi sesama warga masyarakat untuk saling membantu. Kami juga memang terbiasa akan kerja gotong royong. Tapi terkadang terkendala karena ada yang kerja sebagai buruh..." (wawancara tanggal 27 November 2014)

Indikasi ini memperlihatkan bahwa betapa besar kesadaran masyarakat di Desa Sidorukun Kecamatan Randangan untuk berpartisipasi dalam pembangunan.

\section{Faktor Ekstern yang meliputi :} Kepemimpinan Pemerintah 
Telah dikemukakan pada bagian terdahulu bahwa partisipasi masyarakat dalam pembangunan di Desa Sidorukun Kecamatan Randangan pada khususnya tidak timbul begitu saja melaikan terpengaruh oleh beberepa faktor dan salah satunya adalah kepemimpinan pemerintah setempat.

Karena masyarakat adalah merupakan paduan dari beberapa individu yang mempunyai sifat/karakter yang berbeda-beda, maka untuk memadukannya diperlukan suatu kekuatan yakni kemampuan pendinamisan oleh pimpinan pemerintah, dalam hal ini adalah pemerintah desa. Kepemimpinan yang baik dan mampu menyatu dengan karakter masyarakat yang dipimpin dalam mambina dan mengarahkan masyarakat untuk berpartisipasi dalam pembangunan, akan tetapi terjadi sebaliknya jika kepemimpinan yang diterapkan oleh pemerintah bertentangan dengan sifat dan karakter dari masyarakat yang dipimpinnya.

Berhasilnya

masyarakat berpartisipasi dalam pembangunan diperlukan adanya kepemimpinan yang dapat menyatu dengan sikap dan karakter masyarakat setempat, karena dengan kepemimpinan yang baik dan terarah oleh pemerintah maka jelas akan mendorong masyarakat untuk patuh dan taat kepada pemerintah dan kebijksanaan dalam pembangunan akan dilaksanakan dengan baik tanpa merasa ada unsur paksaan atau keterpaksaan.

Dari hasil uraian pada pembahasan diatas penulis dapat menarik benang merannya dimana Kinerja Kepala Desa Dalam Pembangunan Infrastruktur Desa Sidorukun Kecamatan Randangan Kabupaten Pohuwato, dalam Mengkoordinasikan kegiatan pemberdayaan masyarakat, Mengkoordinasikan upaya penyelenggaraan ketentraman dan ketertiban umum dan mengkoordinasikan penerapan dan penegakan peraturan perundangundangan masih kurang atau tidak jalan, begitu pula pada pembangunan infrastruktur desa adanya partisipasi aktif masyarakat dalam pembagunan, Adanya rasa tanggungjawab masyarakat terhadap pembangunan dan Kemampuan masyarakat desa untuk berkembang telah dapat ditingkatkan ini juga tidak jalan. Sedangkan Faktor penghambat kinerja kepala desa dalam pembangunan infrastruktur di desa Sidorukun Kecamatan Randangan Kabupaten Pohuwato dimana Faktor Intern terdapat Faktor Kesadaran atau Kemauan dan 
Jurnal Politik dan Sosial Kemasyarakatan

Vol 11 No 3 (2019) : Desember 2019

Faktor Ekstern yakni Kepemimpinan Pemerintah.

Hal ini dapat disimpulkan melalui hasil penelitian yang ditemukan dilapangan menunjukkan bahwa terdapat kesesuaian teori yang dikemukakan oleh Taliduzuhu Ndraha (1991:23) yang diukur melalui indikator Independen dan Dependen menunjukkan bahwa dalam mengukur kinerja maupun keberhasilan Kepala Desa dalam pembangunan Infrastruktur di Desa Sidorukun Kecamatan Randagan dapat dilihat dari kedua faktor tersebut di atas.

\section{KESIMPULAN}

Berdasarkan hasil penelitian yang telah dilaksanakan di desa sidorukun kecamatan randangan kabupaten pohuwato dapat diperoleh kesimpulan sebagai berikut:

1. Kinerja kepala desa dalam pembangunan infrastruktur desa Sidorukun Kecamatan Randangan Kabupaten Pohuwato, terlihat pada mengkoordinasikan kegiatan pemberdayaan masyarakat, mengkoordinasikan upaya penyelenggaraan ketentraman dan ketertiban umum dan mengkoordinasikan penerapan dan penegakan peraturan perundang-undangan masih kurang atau tidak jalan, begitu pula pada pembangunan infrastruktur desa adanya partisipasi aktif masyarakat dalam pembagunan, Adanya rasa tanggungjawab masyarakat terhadap pembangunan dan Kemampuan masyarakat desa untuk berkembang telah dapat ditingkatkan hal ini tidak jalan.

2. Faktor penghambat kinerja kepala desa dalam pembangunan infrastruktur di desa Sidorukun Kecamatan Randangan Kabupaten Pohuwato masih dipengaruhi faktor intern seperti faktor kesadaran atau kemauan dan faktor ekstern yakni kepemimpinan pemerintah itu sendiri.

\section{Saran}

Berdasarkan uraian dan kesimpulan yang telah dipaparkankan sebelumnya maka penulis mengemukakan saran-saran sebagai berikut :

1. Perlu adanya perbaikan kinerja kepala desa dalam pembangunan infrastruktur di desa Sidorukun dan pembentukan perda yang mengatur tentang koordinasikan kegiatan pemberdayaan 
masyarakat, penyelenggaraan ketentraman dan ketertiban umum.

2. Perlu adanya peningkatan partisipasi aktif masyarakat dalam pembagunan, agar masyarakat turut bertanggung jawab terhadap pembangunan dan kemampuan masyarakat desa untuk lebih ditingkatkan serta kesadaran dan kemauan memiliki jiwa kepemimpinan yang adaptif .

\section{Daftar Pustaka}

Arikunto Suharsimi, 1996. Prosedur Penelitian, Jakarta, Rineke Cipta.

Dwiyanto, Agus, 1995. Penilaian Kinerja Organisasi Publik, Jurusan Ilmu Administrasi Negara,Fisipol UGM, Yogyakarta.

Hamdi Muchlis, 2002. Bungan Rampai

Pemerintahan, Yarsif Watampone, Jakarta.

Handoko H, 2000. Manajemen Personalia

Dan Sumber Daya Manusia, Yogyakarta, BFFEYogyakarta.

Harbani Pasolong, 2008. Teori Administrasi Publik, Alfabeta, Bandung.

Hendra, J.P., 2002, Organisasi Publik, (Kasus di Dinas Lingkungan Hidup
KabupatenPurwakarta) , Tesis tidak diterbitkan. Yogyakarta: Program Pasca Sarjana MAPUGM.

Henry. S, 1995, Manajemen Sumber Daya Manusia, Bagian Penerbitan STIE YKPN, Yogyakarta.

Inu Kencana, Djamaludin Tandjung, Supardan Modeong (1999). Ilmu

Administrasi Publik,Jakarta,

Rineke Cipta

Irawan, P.1997. Analisis Kinerja:Panduan Praktis Untuk Menganalisis Kinerja Organisasi,Kinerja Proses dan Kinerja Pegawai, LAN RI, Jakarta.

Nasution, S, 2002. Metode Penelitian Naturalistik Kualitatif, Tarsito, Bandung.

Nasution,S, 2002. Metode Penelitian Naturalistik Kualitatif, Tarsito, Bandung.

Ndraha, Taliziduhu. 1991. DimensiDimensi Pemerintah Desa. Jakarta: Bumi Aksara.

Osborne, David \& Ted Gaebler. 1996. Reinventing Government : How The EnterpreneurialSpirit Is Transforming The Public Sector, The Adidson Wesley Publishing CompanyInc. 